\title{
"FAZER" (E NARRAR) EXPERIÊNCIA NA PESQUISA E NA FORMAÇÃO DE PROFESSORES NARRADORES
}

\author{
“DO" (E NARRATE) EXPERIENCE IN RESEARCH AND TEACHER \\ TRAINING STORYTELLERS
}

\section{“HACER”(Y NARRAR) EXPERIENCIA EN LA INVESTIGACIÓN Y EN LA FORMACIÓN DEL MAESTROS NARRADORES}

\author{
Carmen Lúcia Vidal Pérez* \\ Professora da Faculdade de Educação e do Programa de Pós-graduação em \\ Educação da Universidade Federal Fluminense \\ Aline Cântia Corrêa Miguel ${ }^{* *}$ \\ Narradora de histórias, pesquisadora em memória cultural e na formação de \\ professores na Universidade Federal Fluminense
}

Resumo: O artigo busca potencializar o debate sobre a pesquisa e a formação de professores narradores a partir da experiência cotidiana, problematizando o enfoque narrativo como dispositivo de formação e de investigação. Tomamos como ponto de conexão entre as formulações de Walter Benjamin e de Jorge Larrosa a relação experiência-linguagem para pensar outros possíveis para a pesquisa e para formação de professores a partir da narrativa e vislumbramos, na articulação da ideia de "limbo" (Larrosa) com o conceito de "terna empiria" (Benjamin) um potente diálogo que pode se desdobrar em novas formulações para o uso da experiência e da narração no campo da pesquisa em educação e a formação de professores.

Palavras-chave: Professores narradores. Formação de Professores. Pesquisa em Educação. Experiência. Narrativa.

\footnotetext{
* Pós-doutora em Filosofia e História da Educação pela Universidade Estadual de Campinas; Doutora em Educação pela Universidade de São Paulo.

** Mestre em Estudos Literários pela Universidade Federal de Minas Gerais; Doutoranda em Educação pela Universidade Federal Fluminense.
} 
Abstract: The article seeks to enhance the debate on research and training of teachers narrators from everyday experience, questioning the narrative focus as training and research device. We take as a connecting point between the formulations of Walter Benjamin and Jorge Larrosa the relationship experience-language to think about other possible for research and teacher training from the narrative and we see, in the articulation of the idea of "limbo" (Larrosa) with the concept of "gentle empiricism" (Benjamin) a powerful dialogue that can unfold in new formulations for the use of experience and narration in the field of educational research and teacher training.

Keywords: Teachers narrators. Teacher training. Research in Education. Experience. Narrative.

Resumen: El artículo tiene por objeto profundizar el debate sobre la investigación y la formación de los maestros narradores de la experiencia cotidiana y señalar el enfoque narrativo como el dispositivo de investigación y de formación. Hemos buscado un punto de conexión entre las formulaciones de Walter Benjamin y Jorge Larrosa en la relación experiencia y lenguaje para pensar en otras possibilidades para la investigación y para la formación con la narrativa y vemos, en la articulación de la idea de "limbo" (Larrosa) con el concepto de "empirismo suave" (Benjamin) un poderoso diálogo que puede desarrollarse en nuevas formulaciones para el uso de la experiencia y de la narración en el campo de la investigación educativa y la formación del profesorado.

Palabras clave: Profesores narradores. Formación de Maestros. Investigación en Educación. Experiencia. Narrativa.

\section{INTRODUÇÃO}

É nesse caos de começo de milênio que a imaginação criadora pode operar como a possibilidade humana de conceber o desenho de um mundo melhor. Por isso, talvez a arte de contar histórias esteja renascendo por toda parte.

Regina Machado

A partir da década de 70 do século XX, as cidades começam a assistir ao movimento de retorno e de valorização da arte de contar histórias, em diferentes partes do mundo. Neste novo contexto, a arte narrativa é ressignificada, ultrapassando os muros da escola e os espaços das bibliotecas e instigando reflexões. É quando a narração passa a ocupar os teatros, hospitais, empresas, parques, centros culturais e outros locais. 
É o contador de histórias que, inserido em uma comunidade de tradição escrita, traz um repertório de histórias ancestrais ou literárias, memorizadas ou aprendidas pela leitura. Ele se utiliza do texto literário escrito ou oral para criar uma apresentação artística e se encontra em situações muito diferentes daquelas que estavam o contador tradicional. O ambiente é um deles: o novo narrador conta para um público geralmente desconhecido, em um local que não é sua comunidade ou família e também não vê as pessoas no dia seguinte. O contexto é outro, ainda que continue a reunir pessoas pelo encantamento, "algo na natureza humana, com raízes bem plantadas num mundo mágico e encantado, parece guardar-se intocável.” (MATOS, 2005, p. 23).

Dialogar com as experiências dos/das contadores/as de histórias pressupõe também recuperar como, historicamente, essa prática foi sendo construída pela humanidade. A figura do narrador permanece viva no mundo contemporâneo e esta presença é alimentada pelo número cada vez maior de ouvintes que buscam a voz deste contador de histórias. No entanto, não podemos compreender o ofício de contar histórias na atualidade como uma sobrevivência do passado no presente. Ao contrário, é muito mais uma experiência do presente do que tão somente a recuperação ou preservação. Certamente, houve uma transformação na maneira como o narrador cumpre sua função e por isso é necessário acompanhar sua trajetória.

Para nos ajudar a compreender estes caminhos, Walter Benjamin traz uma contribuição fundamental em sua denúncia sobre "a extinção da arte de narrar", desvelando o silenciamento que vai sendo imposto a toda uma geração. Na década de 30, Benjamin escreveria sobre o empobrecimento da experiência, um novo tipo de barbárie, uma nova forma de estar no mundo sem vinculação com o passado e com parcas oportunidades de intercâmbio.

O narrador Fabiano Moraes ${ }^{1}$ nos conta uma história sobre a perda da experiência e a desvalorização do processo de morte enquanto da arte de narrar.

1903. Um homem retorna de seu trabalho por uma rua calçada com pedras. Passa por cavaleiros, carroças, pessoas caminhando, cumprimenta quase todas as pessoas que encontra em seu caminho e chega à rua onde mora. Um acendedor de lampiões traz luz à via escura. Um bebê lança ao ar seu primeiro choro estridente, nascido de parteira na casa vizinha, em pleno Rio de Janeiro. O homem chega à sua casa, abre a imensa porta com uma chave enorme. As paredes são grossas e em casa, com o lampião e duas lamparinas acesas ele, mais tarde, conversa com os familiares numa longa mesa de jantar. Nela eles trocam histórias do dia, da vizinhança, da vida. Todos se reúnem, trocam olhares e compartilham suas vozes. 
1937. Aquele bebê, nascido de parteira em 1903, conta agora 34 primaveras. Ele volta de bonde do seu trabalho, cumprimenta grande parte dos passageiros, seus conhecidos, o motorneiro e o cobrador. Chega próximo de sua casa, desembarca e caminha pela via iluminada por lâmpadas elétricas. Vê carros, cavalos, carroças e pedestres em seu caminho e conhece grande parte das pessoas que encontra. Abre a comprida porta do seu sobrado com uma chave ainda grande (aquelas do tempo em que ainda dava para ver pelo buraquinho da fechadura). Em casa, sua família se reúne no começo da noite na sala de jantar. O rádio é a atração principal. Todos, juntos, escutam as histórias contadas pela caixa enorme que transforma ondas eletromagnéticas em ondas sonoras, transmitindo músicas, jogos de futebol, informações, histórias e romances. Nas radionovelas os ouvintes imprimem, ainda, sua imaginação. A partir do som gerado por cascas de coco, cada um imagina um cavalo diferente. $\mathrm{O}$ rosto da mocinha e a cara do coronel são uma criação mental pessoal. Todos ainda se reúnem e trocam olhares, embora durante a história já não compartilhem suas vozes.

1969. O bebê nascido de parteira na cidade do Rio agora é avô com os seus 66 anos de idade, e mora num apartamento, no oitavo andar de um prédio com elevador de porta pantográfica. Seu neto mais velho retorna da sua escola no ônibus que trafega pelo asfalto da cidade, mas raramente o jovem encontra algum conhecido dentro do coletivo. Ele chega em sua rua e cumprimenta poucas pessoas. No seu prédio os vizinhos são seus conhecidos. Toma o elevador, chega à porta do apartamento e a abre com uma chave menor e fina, daquelas que ainda usamos hoje em dia e que já não dá mais para ver do outro lado da porta pela fechadura. Cumprimenta seus pais, seu avô e juntos jantam. Depois do jantar todos se sentam na poltrona da sala para assistirem aos programas no televisor preto e branco, uma caixa enorme com luzes acesas lá dentro (as antigas válvulas) e com um anteparo azul ou tricolor na frente da tela. Agora as histórias exibidas através das telenovelas já não favorecem a ação de criar as imagens mentais: a imaginação. As imagens vêm prontas. No entanto todos ainda se reúnem. Mas durante a história já não trocam olhares e nem compartilham suas vozes.

2003. O bisneto daquele bebê nascido de parteira em 1903 retorna à sua casa de metrô. Não encontra sequer um conhecido seu. Desce na estação onde é quase que levado pela multidão, do vagão até a escada rolante. Chega à superfície e naquele estardalhaço de buzinas, sirenes e anúncios ambulantes não conhece absolutamente ninguém. Atravessa com um grupo enorme de pessoas pela faixa, enquanto os motoristas, nos seus carros parados, esperam apressados, que se acenda a luz verde do sinal. Dobra algumas esquinas entre os prédios altos e o forte cheiro da cidade e chega ao prédio onde mora. Entra sem cumprimentar um dos porteiros, toma o elevador junto a tantos moradores vizinhos desconhecidos, permanece no elevador em silêncio, mirando o infinito, chega ao décimo sétimo andar e caminha pelo longo corredor até o apartamento onde mora, um 
dos dezesseis apartamentos daquele andar. Abre as três chaves da porta, uma delas de quatro segredos, entra, se tranca e vai até o seu quarto. Joga as coisas na cama e liga o seu computador. Acessa a internet, lê, escuta e assiste às tantas histórias que chegam diariamente no seu correio eletrônico. Entra então num programa de conversa a distância onde encontra seu amigo que mora no mesmo apartamento que o seu. Já não se reúnem corporalmente, não trocam olhares diretamente, nem compartilham suas vozes pessoalmente. Os dois, em quartos vizinhos, combinam, através da máquina, de pedir uma pizza. Enfim se encontram na sala do pequeno apartamento. Enquanto isso, aquele bebê, nascido de parteira no que hoje chamamos metrópole, está vivo, em 2003, tendo completado um século de vida, talvez num hospital, no quarto da casa de algum parente ou num abrigo para idosos, quiçá contando para quem queira escutar, em sua voz pausada, fragmentos preciosos de um século de histórias.

Lado a lado com ideias, estilos, compreensões do mundo, construções, teorias e um sem número de criações contemporâneas, surge outro tipo de inquietação: "qual o valor de todo o nosso patrimônio cultural, se a experiência não mais o vincula a nós?" (BENJAMIN, 2008, p. 114). Aqui vale ressaltar uma das dimensões do conceito benjaminiano de experiência sobre a especificidade do relato transmitido pelo narrador. A palavra Erfahrung (experiência), vem do radical fahr - que no antigo alemão significa percorrer, atravessar uma região durante uma viagem. Deslocando-se no espaço, “quem viaja tem muito que contar", afirma Benjamin (1994, p. 198), relembrando um dito popular. Há, contudo, o narrador que, ao contrário do viajante, desloca-se apenas no tempo, por ter passado a vida toda num só lugar. Reconhecido como testemunha das tradições e histórias da sua comunidade, ele também tem o que narrar. Benjamin exemplifica esses dois grupos de narradores - um que se desloca no espaço e outro no tempo - através dos seus representantes arcaicos, respectivamente: o marinheiro comerciante e o camponês sedentário. E se o viajante e o agricultor são reconhecidos por Benjamin como os primeiros mestres na arte de narrar, foram os artífices que a aperfeiçoaram. "No sistema corporativo associava-se o saber das terras distantes, trazidos para casa pelos migrantes, com o saber do passado, recolhido pelo trabalhador sedentário.” (BENJAMIN, 1994, p. 199).

Benjamin ainda escreve que

\begin{abstract}
"Contar histórias sempre foi a arte de contá-las de novo, e ela se perde quando as histórias não são mais conservadas. Ela se perde porque ninguém mais fia ou tece enquanto escuta as histórias, [...] Quando o ritmo do trabalho se apodera dele, ele escuta as histórias de tal maneira que adquire espontaneamente o dom de narrá-las. Assim se teceu a rede em que está guardado o dom narrativo. (BENJAMIN, 2012, p. 221).
\end{abstract}


Para o autor é fundamental que a narrativa esteja vinculada a uma circularidade envolvendo aquele que fala e aquele que escuta e que somente é capaz de ouvir porque se esvazia de pensamentos e, na repetição do trabalho contínuo, é capaz de parar o restante, estar presente e atento à experiência.

Assim, para Benjamin, o contador, quando narra, fala da própria experiência transformada em nova versão do conto. Ele coloca sua experiência a serviço do conto, do próprio conto que lhe permitiu a experiência. Quando narra, os ouvintes mergulham em um universo de imagens e sensações, entregues às vozes que os guiam para terras distantes, para o chamado tempo do "Era uma Vez".

A narradora e pesquisadora Regina Machado reflete sobre este tempo como o de "presentificar, atualizar, como sempre aconteceu com qualquer rito, um universo atemporal, mítico, por meio da experiência pessoal - o agora do sujeito - da escuta, vivência e apreciação de uma história de uma obra de arte, de um símbolo." (MACHADO, 2000, p. 23). Quando ouvimos um conto, temos uma experiência única, que particulariza para cada um de nós, uma construção imaginativa que se organiza fora do tempo da história cotidiana. Para Machado (p. 29), a história só existe quando é contada e se atualiza para cada ouvinte ou leitor. "Era uma vez" quer dizer que a singularidade do momento da narração unifica o passado mítico - fora do tempo - com o presente único - no tempo - daquela pessoa que a escuta e a presentifica. É a história dessa pessoa que se conta para ela por meio do relato universal."

A atualidade trouxe muitas mudanças no jeito de o ser humano relacionar-se com o outro e com os saberes. A aprendizagem diferencia o narrador tradicional e o narrador contemporâneo, sem dicotomias que opõem o narrador tradicional ao contemporâneo, ou seja, o narrador tradicional como o rural e o contemporâneo como aquele que mora na cidade. O narrador tradicional é aquele que é porta-voz de seu grupo e atualiza um acervo de contos e experiências significativas que circula na comunidade. Já a voz do narrador contemporâneo é aquela que não tem a função de representar os anseios coletivos, mas que estabelece uma outra possibilidade de comunicação. O que os une é o fio da experiência. Como nos fala Jorge Larrosa (2002, p. 21):

[...] poderíamos dizer, de início, que a experiência é, em espanhol, "o que nos passa". Em português se diria que a experiência é "o que nos acontece"; em francês a experiência seria "ce que nous arrive"; em italiano, "quello che nos succede" ou "quello che nos accade"; em inglês, "that what is happening to us"; em alemão, "was mir passiert". A experiência é o que nos passa, o que nos acontece, o que nos toca. 
A experiência narrativa não acontece se não nos toca ou nos passa - sejamos nós narradores ou ouvintes.

Tais reflexões nos conduzem a problematizar - seguindo o rastro deixado por Larrosa $(2012,2013,2014)$ a experiência narrativa como "modalidade" de pesquisa e ação formativa. Benjamin (1994), ao denunciar a pobreza da experiência que o mundo dominado pela técnica provoca, tanto pela aceleração do tempo - transformações rápidas e radicais que não conseguimos assimilar pela palavra - quanto pela ausência da palavra comum - que se articula às perdas das referências coletivas - aponta que a experiência que se vive é a de sua própria impossibilidade. Tal impossibilidade de partilha da experiência é reafirmada por Larrosa (2014), que ao reinvindicar o saber de experiência e as linguagens da experiência como saberfazer ${ }^{2}$ da educação nos convida a abandonar as

Linguagens dominantes na pedagogia, tanto a linguagem da técnica, do saber e do poder, como a linguagem da crítica, da vontade e da ação, essas linguagens que não captam a vida, que estão cheias de fórmulas, que se ajustam perfeitamente à lógica policial da biopolítica, linguagens emprestadas da economia, da gestão, das ciências positivas que tornam tudo calculável, identificável, mensurável, manipulável. (LARROSA, 2014, p. 69).

Convite que nos desafia a inventar, na educação "uma forma de pensar, de dizer e de olhar o educativo, que não seja assimilável, nem pela pesquisa técnico-científica - essa que se formularia desde o par ciência-técnica -, nem pela pesquisa crítica - essa que se formularia desde uma teoria da prática." (LARROSA, 2012, p. 287). É ainda Larrosa quem nos desafia ao afirmar em tom de indagação "se o que fazemos, ou o que, os que amparados na palavra experiência trabalhamos em educação gostaríamos de fazer, é ainda pesquisa, outra forma de fazer pesquisa educativa, ou se é, talvez, outra coisa que não pesquisa.” (LARROSA, 2012, p. 287).

Larrosa provoca e responde à provocação nos apresentando outros possíveis para a pesquisa em educação: uma das possibilidades seria a pesquisa centrada no experiência-sentido, para além do par ciência-tecnologia, ou do par teoria-prática que predominam na área das ciências humanas e, em especial, na educação. Um outro possível é a uma alternativa à pesquisa educativa a partir da experiência, do trabalho com a experiência - exercício complexo, pois, como afirma o autor, uma alternativa que é outra coisa que pesquisa educativa porque não pode nem quer ser "pesquisa" (LARROSA, 2012, p. 287). 


\section{EXPERIÊNCIA-SENTIDO EM EDUCAÇÃO}

Para mim, cantar a experiência tem a ver com abrir, nas instituições educativas, um tempo livre, liberado, roubado à necessidade à utilidade, para ver se nesse tempo livre podemos constituir juntos algo assim como um espaço público, da palavra e para a palavra, do pensamento e para o pensamento [...]"

Jorge Larrosa

Experiência é antes de tudo paixão. Não é algo que se acumula, algo que se tem e se constrói durante uma vida. Ao contrário, a experiência é algo que escapa à vida, é algo passageiro, que não cabe em uma técnica ou em uma palavra. É algo que escapa à palavra, algo que não sendo técnica, não pode ser reproduzido. Algo que é único, singular. Assim, experiência não é experimento, não generaliza verdades, não pode ser provocada, causada, não se programa em um mapa de causalidades e efeitos, certezas (PÉREZ; LEITE, 2015, p. 5-6).

A pesquisa como experiência é o que nos acontece - produção coletiva que envolve paixão, atenção, escuta, disponibilidade, sensibilidade na produção de sentidos com o outro. Um acontecimento investigativo (que se atualiza em sua singularidade, que não separa o sensível do inteligível e o atual do virtual), extraordinário, surpreendente e único.

É algo que é único, singular, "porque não se ajusta à ontologia do ser, mas a do acontecer." (LARROSA, 2012, p. 297). A experiência-sentido se faz pesquisaexperiência ${ }^{3}$, ou seja um pensamento que experimenta com a pesquisa, um pensamento que experimenta "com", que ensaia, que põe à prova, que não diz o que é, mas que compõe modos de pensar uma educação e seus contornos.

[...] um pensamento da educação que reclame experiência é um pensamento que ainda tem que ser pensado ou, dito de outro modo, um pensamento que ainda está por pensar ou, melhor, que sempre está por pensar. Por isso ninguém pode antecipar como deveria ser esse pensamento ou que é o que nos poderia dizer. (LARROSA, 2012, p. 295).

É como se a educação precisasse ser outra, precisasse do outro, da alteridade. Talvez como pesquisa alterada pela presença do outro, pela alteridade, seja pura interrogação, seja provisória, arraste-nos de uma pretensão do saber, de saber, mas que se apresente nos gaguejos de um não sei de partida e de chegada. Uma educação e uma existência que se apresenta como experiência é sempre espaço onde predominam 
aberturas onde circulam palavras, sentidos, possibilidades, onde se produz narrativas (PÉREZ; LEITE, 2015, p. 11).

A experiência na educação não é uma alternativa teórica, metodológica, política ou paradigmática. É abertura para o pensamento, para a conversa, para a narração, para a experimentação de diversos modos e em diferentes registros ou, como aponta Larrosa, um tema de um canto.

[...] pelo menos para mim, a experiência foi mais o tema de um canto, de um canto de protesto, de resistência, em primeiro lugar, em direção aos modos como se nos dá a pensar, dizer e seguramente pesquisar em educação, e em segundo lugar um canto de amor ao que se abre ou pode abrir-se como uma relação intensiva com a realidade e com a linguagem. (LARROSA, 2012, p. 291).

Cantar a experiência na educação é apostar na potência, naquilo que ainda "não sendo é": multiplicidades, singularizações, acontecimentos que, quem sabe poderão nos oferecer pela diferença de experiências uma outra educação, uma educação que possa ser outra. Ou seja, falar de experiência em educação é uma forma de falar da diferença, daquilo que por ser outro jamais poderá ser mesmo, pois a experiência é única e singular, "porque não se ajusta à ontologia do ser, mas a do acontecer." (LARROSA, 2012, p. 297).

\section{A POLÍtiCA DA TERNA EMPIRIA E A PESQUISA QUE NÃO SE QUER PESQUISA}

Para Larrosa (2012), a experiência não é uma alternativa na pesquisa em educação, um novo enfoque, um novo modelo ou um novo paradigma como muitos defendem. Para o autor o trabalho com a experiência não se constitui em alternativa à pesquisa em educação, pois é outra coisa que não pode nem quer ser pesquisa.

Se a experiência não é uma alternativa à pesquisa em educação, se é outra coisa que não pode nem quer ser pesquisa, resta a pergunta: que relações podemos tecer entre experiência e educação?

Larrosa cita Martin Jay, que considera a experiência como uma "ideia confusa" que ocupa (e ocupou) reflexões profundas por parte de diversos pensadores de tradições filosóficas distintas, pois "experiência é um significante suscetível de desencadear profundas emoções nos que lhe conferem um lugar de privilégio em seu pensamento." (JAY apud LARROSA, 2012, p. 290). Mais do que tentar definir ou explicar o conceito de experiência buscamos compreendê-lo em sua força e em sua 
potência no que se refere ao seu uso (não aplicação - uso) no campo da educação, da pesquisa em educação e na formação de professores.

$\mathrm{Na}$ tentativa de tecer relações que nos permitam compreender as complexas tramas que se engendram entre experiência e educação seguimos o rastro das palavras de Larrosa (2012, p. 292):

[...] se se começa a subordinar a experiência à prática e se faz dela algo que tem a ver com a melhoria da prática, se se começa a fazer da experiência um conceito, ou um método, se a experiência começa a funcionar no campo educativo como um novo paradigma de pesquisa ou como uma alternativa para a pesquisa, como outra pesquisa, então, quiçá, vamos ter que ir com a música (com o canto) a outra parte. E abandonar, com todas as suas consequências, o dispositivo mesmo da pesquisa.

À problematização da experiência vincula-se à problematização da pesquisa no campo da educação. Tal formulação fratura o arcabouço cartesiano que (ainda) fundamenta a maioria das pesquisas em Educação e nas Ciências Humanas. Se confortavelmente substituímos o sujeito cognoscente (cartesiano), pelo sujeito da experiência, seja na pesquisa em educação, seja na formação de professores, a provocação de Larrosa nos desloca e nos conduz ao encontro de um sujeito que "não se caracteriza por sua força, mas pela sua fragilidade, por sua vulnerabilidade, por sua ignorância, por sua impotência [...]" (LARROSA, 2012, p. 290). E, se a experiência escapa ao saber, ao poder e à vontade do sujeito, por que falar de sujeito da experiência? Como falar de experiência sem um sujeito (mesmo coletivo)? Como pensar a experiência na educação?

Como resposta, Larrosa (2012) investe na invenção de um pensamento não pensado, um pensamento que segundo ele tem que ser inventado, experimentado: “[...] um pensamento da educação que reclame experiência é um pensamento que ainda tem que ser pensado ou, dito de outro modo, um pensamento que ainda está por pensar ou, melhor, que sempre está por pensar [...]”' (LARROSI, 2012, p. 291).

Ao apostar no vazio do pensamento Larrosa nos convida a pensar a experiência como potência do pensamento e provoca o deslocamento da relação pesquisa-experiência - não mais como composição binária, mas como um entre "outra" pesquisa e "outra coisa que" pesquisa. Tal deslocamento nos coloca numa espécie de limbo discursivo, pois aquilo que fazemos, ou entendemos como pesquisa, não é aceito, e embora não seja rechaçado, é muito pouco considerado como pesquisa.

A ideia de limbo nos inspira, a partir das formulações de Larrosa, a pensar outros enunciados para a pesquisa: 
(i) o limbo como lugar de tudo o que escapa à lógica da pesquisa, tanto do que ela é, quanto deveria ser;

\section{"As borboletas"}

Os brinquedos e as brincadeiras que eu e meus irmãos inventávamos eram muitas e às vezes perigosas. Assim eram os nossos domingos e as brincadeiras que sempre começavam no terreiro se estendiam pelo pomar e até mesmo pelas pastagens, onde grandes árvores se tornavam palco de pique pega e lugar de acrobacias, um verdadeiro picadeiro no qual a rede que nos protegia de um possível tombo era o chão coberto de vegetação rasteira.

Era no pomar que quase sempre nosso caminhar era interrompido pelo voo leve e articulado das borboletas. Não era qualquer borboleta, as que atraiam nossa atenção eram as grandes, aquelas de asas azuis e que tinham no meio de cada par de asas desenhos bem singulares que ora imitavam um buraco negro e às vezes se confundiam com o olhar de Mona Lisa que sempre nos observava.

Correndo de um lado para o outro, espera pacientemente que as borboletas pousassem em uma laranja em estado de apodrecimento. Depois de muitas tentativas, como um gato que prepara seu ataque fatal à presa, conseguia realizar o tão desejado plano: tocar nas asas de uma borboleta.

No entanto, o que mais me seduzia nas borboletas não era o seu voar, nem seus olhos nas asas, mas o pó mágico que suas asas azuis e brilhantes liberavam nos meus dedos quando as tocava. Nesse instante meu coração se enchia de felicidade e medo.

Ainda paralisado olhando para a ponta dos dedos coloridos com aquela purpurina natural, lembrava-me de um conselho dado pela minha avó: "Não passe aquele pó que as borboletas soltam nos olhos, eles nos deixam cegos". Que confusão! Aquela frase me impactava e estranhamente me motivava.

Depois de minutos olhando aquele pó e colorindo minha mão e tudo que tinha por perto, corria para o tanque onde lavava minha mão, retirando o pó e apagando a possibilidade da cegueira.

(ii) O limbo como lugar daqueles não que falam como investigadores, mas como homens ordinários, no dizer de Certeau, daqueles para quem falar é se expor;

Tiro chapéu e me apresento. Uma autobiografia ${ }^{5}$

O sujeito viajava de uma cidade à outra, até que num desses lugarejos distantes, sentindo fome, foi até o único restaurante da região. Lugar simples, mesas de madeira. Toalhas de chita. Comida caseira. Mas o mais importante: a comida era gostosa. 
O moço sentou-se numa das mesas e esperou um pouco, até que foi atendido por uma moça bonita e simpática que lhe entregou o cardápio. Ele verificou as poucas opções e logo escolheu:

- Filé, farofa, feijão, fritas e frango.

- E para beber, o que vai querer?

- Fanta, faz favor!

A moça tomou nota, foi até a cozinha, e logo em seguida retornou trazendo o prato, o copo, o garfo, a colher e um guardanapo. Ele conferiu, olhou para ela e avisou:

- Falta faca!

- É mesmo meu senhor! Me desculpe!

Ela foi até a copa, trouxe a faca e, logo em seguida, estava servindo a refeição completa.

Ele, com fome, pôs-se a comer.

Quando terminou sua refeição, a garçonete voltou até a mesa e perguntou:

- E então, senhor, como estava a comida?

Ele fez uma cara de satisfação e respondeu:

- Fabulosa! Fantástica!

- Nós também temos sobremesa. O que o senhor gosta de comer depois do almoço?

- Frutas.

- Sim, nós temos salada de frutas, doce de mamão, doce de figo, doce de banana.

- Figo, filha, faz fineza!

A moça trouxe o doce, ele comeu tudo e bebeu até a calda. Ela então perguntou:

- O que o senhor achou do nosso doce?

- Fenomenal! Formidável!

A moça já tinha observado o fato de que, até então, todas as palavras que aquele homem havia pronunciado começavam com a letra "F". Não aguentando mais de curiosidade, ela perguntou: - O senhor me desculpe, mas eu observei que todas as palavras que o senhor falou começam com a letra "F". Qual é o nome do senhor?

- Francisco Ferreira Fagundes Filho.

- E o senhor é o quê?

- Ferreiro, filha!

- Ferreiro? Mas o que o senhor faz?

- Faço faca, facão, ferrolho. Fabrico ferradura, foice.

- Nossa! E de onde o senhor vem?

- Franca.

- Puxa! Eu estou tão impressionada que vou trazer um café para o senhor. E é por conta da casa, viu?

- Faz favor, filha!

A moça trouxe o café. Serviu. Ele levou a xícara à boca, bebeu e engoliu forçado. Ela notou e perguntou:

- O senhor não gostou do nosso café não é?

Ele fez que não respondendo:

- Fraco, frio, formiga no fundo.

- Mas como é que o senhor gosta?

- Forte e fervendo!

A garçonete trouxe um novo café, desta vez forte e fervendo. $\mathrm{O}$ homem bebeu contente. 
Depois de tomado o café, a moça, cada vez mais encantada com aquele tipo curioso fez um desafio:

- Olha, se o senhor falar mais cinco palavras começadas com a letra "F" o senhor não precisa pagar a conta, viu?

Ele olhou pra ela, deu uma piscada de olho, e disse:

- Fazendo fiado, fico freguês, formosa flor!

Ela abriu um sorriso, agradeceu e se despediu. E quando a moça deu meia volta pra voltar

para a cozinha ele ainda deu aquela olhada e fez:

- Fiu-fiu!

Pois esta história aconteceu. O moço do restaurante é o meu pai.

Por isso meu nome ficou

sendo Fabiano. Já o sobrenome Moraes vem de parte da minha mãe: a garçonete.

(iii) O limbo como o lugar dos que não tomam o real como um tema ou um

objeto, mas como uma intensidade, como um afeto, como o que lhes acontece, como uma experiência.

\section{O caminho da escola ${ }^{6}$}

As minhas idas e vindas da escola não eram iguais apesar de sempre fazer o mesmo trajeto. $\mathrm{O}$ segredo era muito bem guardado e não tinha senha para entrar.

Saía de casa atravessava a rua, passava pelo parquinho, atravessava a outra rua, passava pelas quadras de futebol e de lá já via a escola e o portão branco semiaberto esperando por mim. Não me lembro o motivo pelo qual eu ia e vinha sozinha, mas acho que a minha irmã estudava no $2^{\circ}$ turno e eu era do $1^{\circ}$ turno. É a única explicação que me ocorre neste momento.

Bom, esse trajeto eu fazia todos os dias para a escola e o trajeto de volta era o mesmo caminho, porém invertido.

As minhas caminhadas variavam muito de acordo com o momento. Geralmente, ao atravessar a primeira rua eu iniciava a minha viagem até o próximo porto. Passava pelos muros já flutuando e quando menos esperava eu me via querendo alcançar as nuvens com os meus pés toda vez que o balanço subia e ao descer imaginava estar aterrissando de algum lugar, de uma espaçonave. Nessa hora do dia não havia lua no céu, mas ao subir o escorrega pelo lado contrário só pensava em chegar ao topo e pisar na lua. Na televisão tinha visto a chegada do homem à lua, imagem única dos astronautas pulando e flutuando, tudo em câmera lenta e em branco e preto. Até hoje essa imagem está na minha memória. Ser astronauta, ver o planeta desde lá do alto. Era isso que me fazia sempre buscar as alturas. Subia os muros, as árvores, os balanços, as grades e tudo que poderia significar céu.

E assim eu caminhava até perceber a minha escola "Terra à vista"! Lá estava o portão branco entreaberto, um pouco distante da primeira escadaria. No meio havia o mastro da bandeira chilena, sempre hasteada. Chegava finalmente e na maioria das vezes o que me esperava era o silêncio do pátio da escola. Os meus companheiros já tinham partido, marchando para sala logo após 
o hino nacional. Eu atravessava aquele pátio oceânico que parecia não ter fim, até chegar a outra margem onde se encontrava a minha sala, entrava, me aproximava da professora, que sempre me observava querendo entender o porquê do atraso e movia a cabeça me desaprovando. Mas ela jamais descobriu as minhas viagens secretas realizadas nas idas e vindas da escola.

(iv) O limbo como lugar da narrativa, em que o empírico seria terno por seduzir o "observador", o ouvinte, o leitor...

\section{O Piano ${ }^{7}$}

Em minhas lembranças de infância, o piano de minha irmã foi objeto de muito encanto e mistério.

Desde sua mudança para nossa casa, a preocupação era tomada de muita expectativa e cuidados. Como levaríamos o piano para o segundo andar? Causaríamos ao querido companheiro algum dano? O piano sempre foi desejado por minha família, pois a sua aquisição sempre demandou muito esforço por intensas economias em direção a sua compra. Estudar piano, comprar o instrumento musical, as audições eram recheadas de mistério e magia.

Quando chegaram os móveis em nossa casa não houve tanto alarde quanto a entrada por último do piano. Cordas, força, muita gente para garantir a entrada do nosso companheiro tão ilustre e, como era desejado, o piano chegou sem problemas, sendo disposto junto a duas paredes, bem no canto desenhando formosamente um triângulo quase equilátero.

Esse triângulo permeia minha imaginação até os dias atuais. Atrás do piano, no meio desse triângulo formado, quase uma escultura milimetricamente planejada, entrava meu corpinho de sete anos para guardar coisas, objetos encontrados, brincar de esconde-esconde, era um lugar só meu. Nem a faxineira se atreveria entrar em meu triângulo. Como saberia se salvar de tanto peso caso desejasse limpar o meu triângulo? Minha mãe bem a questionava se haveria possibilidade, logo descrevia os horrores de tal aventura e todos desistiam das limpezas e o meu lugar escondido voltaria a ser somente meu.

Estar atrás do piano era tão fantástico quanto observar suas teclas, seu som, sua presença naquela casa. O piano era um objeto que nas mãos de minha irmã se transformava em um deleite quase espiritual. Havia uma música, O Galope do Diabo, que de fato nos fazia entrar nos saltos e inquietudes que trazia tal melodia. O compasso tranquilo se misturava com os galopes intensos gerando uma ansiedade pelo que viria após desse período majestoso. Não havia ninguém que não se envolvesse com a grandiosidade da música. No mesmo quarto havia uma poltrona destinada para aquele que desejasse ouvir a enigmática apresentação de sua potência musical, minha irmã e o piano.

Para mim, o piano era um desafio inatingível e símbolo de um esforço que poucos alcançariam se não vivessem ou compartilhassem as horas e horas de estudo destinadas para domar tal instrumento.

Preferia ficar com meus objetos escondidos e brincadeiras particulares em um mundo mágico de criança atrás de um objeto 
que somente adultos poderiam ter acesso. Eu aprendi com o piano que o valor que atribuímos as coisas ou as pessoas está diretamente relacionado com as histórias, com o esforço empenhado e com o sentimento. Naquele momento, somente naquele momento o piano triunfou. O piano ensinou a todos que os objetos levam as crenças, as expectativas, a cultura de uma época. Logo que passamos a destinar nosso tempo para o dia a dia do corre-corre, para a busca do ter, do espírito mercantil, o nosso piano perdeu sua posição e sua coroa.

Ficaram as lembranças de momentos envolvidos pela beleza da música que possui ainda seu espaço reservado para aqueles que ainda resistem aos ditames da vida moderna. Quanto a mim, o piano possui significado especial de infância, descobertas, do triângulo do $2^{\circ}$ andar da casa, dos objetos escondidos que somente eu teria acesso. Pedrinhas, fósforos, bonecas muito velhas que não gostaria de doar, bolas de gude que encontrava, enfim rastros de minha criancice.

Ensaiamos com Benjamin e Larrosa e buscamos experimentar outros possíveis para a pesquisa em educação e a formação de professores a partir da experiência e da narração. Nesse sentido, o termo "experimentar" é uma variação do termo "ensaio" ou "ensaiar", pois entendemos que:

[...] ensaiar como experiência é uma forma de degustar. A degustação como prova é na maior parte das vezes experimentar aquilo que ainda não está pronto, para poder, entre outras coisas, dizer o que falta, como se apresenta o tempero. Nas degustações, sentimos cheiro, textura, paladar, temperatura, então colocamos à prova aquilo que ainda não se concluiu, ainda não é. Aquilo que está se fazendo, aquilo que poderá vir a ser. Se o ensaio é uma forma de degustar, assim como frequentemente falamos (como ensaio de uma peça, ensaio de um espetáculo), no ensaio experimentamos aquilo que, não estando pronto, precisa passar por uma prova, para dele se dizer o que ainda falta. Apresentar um ensaio então seria como apresentar um texto infantil, infante, um texto-infância, um texto menor, um texto ainda por vir, um texto porvir, um texto ainda não pronto, um texto que ensaia, para que ele se experimente. Então, aquilo que parece lacunar, tem para nós o sentido de potência de criação [...] (PÉREZ; LEITE, 2015, p. 7).

Assim, articular a ideia de limbo (Larrosa) com o conceito de terna empiria (Benjamim) é uma tentativa de pensar um pensamento não pensado sobre a pesquisa e formação de professores. Um ensaio de pensamento, inacabado..., incompleto..., uma experimentação...

Terna empiria, conceito benjaminiano engendrado na experiência, que engendra outra experiência de pesquisa, ou outra coisa que pesquisa, ou uma pesquisa outra - uma política de pesquisa que exige o abandono da razão arrogante e tem como fundamento os acontecimentos e as experiências. Uma forma de investigação que é também uma invenção. 
$\mathrm{Na}$ pesquisa inventada o empírico desacomoda, desterritorializa "verdades", escapa às análises totalizantes e impõe o exercício da terna empiria (BENJAMIN, 1994). O conceito de terna empiria funciona como uma política de investigação “isenta de preconceitos, e mesmo audaciosa, mas ao mesmo tempo terna [...] uma terna empiria que se identifica intimamente com o objeto e com isso transforma-se em teoria", como aponta Benjamin (1994, p. 103).

\section{Corpos que costuram, lugares do escrever ${ }^{8}$}

Aquele gabinete marrom, que já esteve na sala, no quarto dela e hoje habita a varanda no fim da casa, me parece o seu objeto mais antigo. Ao subir a tampa lá está ela escondida - a máquina. Branca, com algumas letras que ainda não podia ler estampadas em seu corpo e na extremidade uma agulha. Sobre sua cabeça as linhas coloridas e abaixo, o tecido. À sua frente, aberta a porta, um vão, onde as pernas de minha mãe se encaixavam, e pedais, onde repousava os pés que, ao contrário das mãos, pareciam apenas obedecer a engrenagem. Maquinaria de uma peça só, não fossem as mãos. Essas, antes de dominar a máquina, desenhavam os modelos, tantas vezes copiados das vitrines, na última folha de um de meus cadernos.

Riscados com giz, ora rosa ora azul, vinham saias que davam notícias de inflação e desemprego, vestidos que derramavam os últimos capítulos da novela, blusas que estampavam retratos da fartura e da fome. Os moldes recortados sobre algum jornal, ali também recuperava a notícia para logo, tão qual na feira, virar "embrulho de peixe". Desta cena nasceram roupas de batizados e aniversários, toalhas de nossas mesas, adereços para as danças na escola, minhas e de minhas amigas e remendos de todos os tipos, inclusive e tão especialmente dos uniformes de escola. E era ao chegar da minha que brincava:

Uma folha de papel ofício dobrada ao meio, com as teclas de letras desenhadas, servia de treino. A porta da estante preta era aberta, e a menina colocava sobre ela: o telefone, o estojo, meia dúzia de livros e papéis, e brincava de escritora (por vezes a jornalista, a romancista ou a professora). Tal qual a costureira recortava, copiava, montava, alinhavava. O som da máquina imaginária era ali o som das teclas que não apertava. Enquanto lá saíam os tecidos transformados em peças de vestuário, aqui saía... nada, a não ser pelo sonho da menina, onde seus romances já listavam entre os mais vendidos. Até que chega a máquina amarela, o mais novo objeto dentro da mesma casa verde, e as teclas passariam a fazer barulho de verdade. A Olivetti chegou para dar conta das tarefas da professora que se formava.

Tal qual nos diz Deleuze, de máquinas-corpos a máquinas-energias. A escritora-costureira não prega um botão, mas ao escrever sente que respeita certo som e ritmo da velha máquina Singer, essa que foi uma das primeiras palavras que leu sem ajuda. Se reparar bem talvez embaixo da mesa repita os movimentos dos pés sob o pedal, e tal qual a costureira seja parte de uma só engrenagem. 
Foi com a costureira-escritora que não escreve livros, mas tecidos, que primeiro atentei para observar os contornos, as texturas, os (des)encaixes e tentar produzir escritas sempre provisórias, alinhavando as ideias sem pretendê-las terminadas verdades. Repetir a gestualidade da costura na escrita, tecendo novas modelagens com movimentos invisíveis, com as sobras de tecidos, de cores nem sempre combinadas. Alfinetar com fazeres/saberes/dizeres para desassossegar. Costurar as palavras e rasgá-las com o que vem puído e desses restos produzir efeitos, outros sentidos, experimentações... Bem, da Singer nunca saiu alta costura e da Olivetti só saíra pequenas memórias.

"Onde não estou, as palavras me acham" (Manoel de Barros, livro sobre o nada).

Como política de investigação e de formação a terna empiria engendra narrativas, encontros e nos desafia a (re)inventar a pesquisa e a formação como experiência narrativa.

\begin{abstract}
A Memória das histórias ${ }^{9}$
A minha infância foi habitada por muitas histórias. Rememoro facilmente a voz de minha avó que cantarolava versos aprendidos entre as colheitas do café. Lembro de uma específica e que começava assim: "Vanceis de certo não sabem quem eu sou. Claro que não, eu sou o Jeca Tatu”. E a voz um pouco mais rouca com um chapéu de lado embalava minha imaginação [...] Recordo das leituras bonitas que fazia minha mãe dos livros que chegavam como tesouros de ouro. E ainda do meu pai, criatura quieta e misteriosa, na varanda de casa, declamando Canção do Exílio. Eu também consigo me lembrar da minha própria narrativa destas histórias. Da imaginação acerca das imagens que povoam aquelas letras ainda tão desconhecidas para mim. Lembro que as decorava de tanto ouvir a voz miúda de minha irmã um pouco mais velha que eu. Depois as narrava para todos que eu encontrava: nas ruas, nas viagens pelo sul de Minas, nos encontros com primos na Zona da Mata e, posteriormente, nos inúmeros diários que mantive dos 06 aos 14 anos.
\end{abstract}

Uma memória carregada de cheiros e palavras que cresceram comigo. E é por causa dela que escolhi trabalhar a literatura pelo viés do narrar. Isto em 2002, quando fui realizar um trabalho numa comunidade quilombola no interior do Goiás e ali encontrei dezenas de guardiões da memória com seus contos e poesias orais. Desta imersão de alguns meses no Kalunga nasceu minha dissertação de mestrado em Estudos Literários, na UFMG. Mas era só o começo: eu jamais poderia imaginar como era profundo o mundo das narrativas e da memória e o seu papel social, cultural e político no país. Poucos anos depois, ao me encontrar com um músico apaixonado por histórias de vida, acabei re-descobrindo a narradora de histórias que morava em mim. Daí começou um trabalho de pesquisa estética sobre a arte de narrar histórias. 
Quando comecei a assistir a grupos de contadores de histórias, tive a oportunidade de ver o espetáculo "Contos de Todos os Cantos", com o narrador Giba Pedrosa e os músicos Gustavo Finkler e Renata Mattar. Imediatamente passei a experimentar o encantamento de ver reunidas diversas manifestações que eu já gostava: a literatura de origem tradicional, os ritmos, as cantigas, as quadrinhas, a brincadeira com a palavra. Neste trabalho específico, estes elementos se mesclavam às histórias de maneira muito harmoniosa e tudo parecia uma coisa só. Ao acordar em mim diversas percepções e sensações, fui descobrindo que o caminho que eu queria seguir era por ali. Depois, assisti a uma apresentação do narrador Bocca e o músico Marcos Boi. Bocca tinha uma musicalidade e um ritmo que me conduziam para qualquer lugar onde ele quisesse. Descobri, tempos depois, que aquilo se chamava cadência. Entrei em um processo profundo de pesquisa e conheci outros trabalhos, como da Regina Machado, de São Paulo, da Gislayne Mattos, Rosana Montalvernne, Beatriz Myhrra e Sandra Bittencourt, de Belo Horizonte, Benita Piedro, do Rio de Janeiro, Ilka xxx, de Santa Catarina, Angela e Joca Monteiro, de Macapá, Linete Matias, de Piaçubu-AL. Ao acumular algumas experiências de narração e conversas com diferentes contadores, passei a me perguntar quais os caminhos para aprender a arte de contar histórias.

Este questionamento se fez ainda mais forte quando comecei a ser convidada para dar formações para educadores. Assim, a ideia de que contar histórias é uma arte que se aprende com arte começou a ser desenvolvida numa pesquisa teórica e prática. Para isso, passei a ampliar uma bibliografia sobre o tema, conhecendo projetos, escutando muitas histórias, entrevistando narradores e professores e vivenciando propostas de aprendizagem.

Entendemos o ato de narrar como ato de conhecimento. Por intermédio da narrativa, professoras e professores tecem uma rede de significantes que traduzem formas (visíveis e invisíveis) de compreender/conhecer o ato educativo. Leal (2009) nos lembra que o ato educativo precisa ser narrado. A narrativa da prática educativa transforma o ato em história - a história de uma experiência que engendra aprendizagens: "aprende quem conta, quem escuta, quem escreve, quem lê. Aprendem todos os que sabem o valor de restituir ao outro um saber que resulta da experiência." (LEAL, 2009, p. 11). Narrativa e experiência transformadas em saber: saberes da experiência feitos que todos e todas possuímos, pois, como nos aponta Freire (1996), somos capazes de travar relações no e com o mundo e experienciá-lo. A experiência é singular, engendra e é engendrada, pelas nossas tentativas de responder os diversos desafios que nos são lançados. As experiências, ao mesmo tempo que produzem conhecimentos potencializam o processo formativo. 
Priorizar, como fazem algumas investigações, a escritura como forma de narrar é uma tentativa, no que se refere ao processo de formação das/os professoras/ es, de resgatar um bem cultural, que historicamente tem sido utilizado como instrumento de interdição de outras formas de ser. A escrita é aqui concebida como um mecanismo capaz de gerar e/ou afirmar diferentes formas de ser, pensar e conhecer. A escrita é um acontecimento.

Escrever e narrar sua experiência é um "estado inédito", que possibilita a/o professora/o se colocar como sujeito de sua própria história: lembrar o vivido é evocar a memória das marcas, reatualizando-as como reminiscências e corporificando-as por meio da linguagem. Mais do que uma leitura, ou releitura, do vivido, este exercício "autopoiético" se caracteriza, do ponto de vista da formação, como aponta Dominicê (apud NÓVOA, 1988) como um processo de apropriação de cada um do seu próprio poder de formação ( PÉREZ, 2003, p. 35).

A narrativa escrita da experiência vivida possibilita ao professor/a, como narrador/a, ampliar o diálogo com o outro. Fundamentadas/os numa concepção que vê a escrita como um ato potencializador de processos reflexivos; entendemos que a formação de professores passa necessariamente pela ação de escrever-narrar-refletir sobre o vivido. Narrar (e escrever) suas experiências é, do ponto de vista da formação, um exercício de autotransformação - narrativa e escrita funcionam como dispositivos de autoconstituição - trabalho que abrange tanto a vida, como o texto: escreve-se para transformar, e nisso consiste a atividade "etopoética" da escrita, lembra-nos Foucault (1992).

Escrever é criar. Escrever é um ato potencializador de processos/movimentos de formação. Escrever é experiência: a palavra escrita é um instrumento que estrutura o movimento de reflexão que a produção da narrativa instaura. A escrita é a pauta a partir da qual as/os professoras/es vão percebendo e experimentando situações limites, ampliando suas fronteiras e desatando os nós do medo e da estagnação para produzir/fabricar novos significados para a experiência e o conhecimento, como na narrativa a seguir - uma experiência de formação de professores de educação infantil em Belo Horizonte. ${ }^{10}$

\section{FAZER EXPERIÊNCIA E NARRAR HISTÓRIAS NA FORMAÇÃO DE PROFESSORES}

[...] fazer uma experiência com algo significa que algo nos acontece, nos alcança; que se apodera de nós, que nos tomba e nos transforma. Quando falamos em "fazer" uma experiência, isso não significa precisamente que nós a façamos acontecer, "fazer" significa aqui: sofrer, padecer, tomar o que nos alcança 
receptivamente, aceitar, à medida que nos submetemos a algo. Fazer uma experiência quer dizer, portanto, deixar-nos abordar em nós próprios pelo que nos interpela, entrando e submetendo-nos a isso. Podemos ser assim transformados por tais experiências, de um dia para o outro, ou no transcurso do tempo.

Martin Heidegger

Em 2007 recebi o primeiro convite para dar um curso de formação em "contação de histórias" para professores da educação infantil. A turma tinha 25 pessoas e comecei contando a história da Árvore Generosa. Em seguida, pedi que cada um escrevesse em um pedaço de papel uma experiência que tivesse sido significativa para eles, independente da fase da vida. Ao terminarem, entregaram-me e eu me afastei da sala por quinze minutos. Fiz uma costura das histórias, introduzi algumas canções e voltei para sala, fazendo a leitura em voz alta.

Instaurou-se naquele momento, o que Regina Machado chama de "aura" dos contos: uma atmosfera que se instala e se espalha "entre e dentro de todos nós, criando uma situação de aprendizagem única que nos faz perguntar: O que acontece quando alguém conta uma história, que efeito é esse que une as pessoas numa experiência singular?" (MACHADO, 2000, p. 21). Quando terminei, a professora Emanuela Melo me disse: “-Às vezes eu era o personagem destas histórias, mesmo que não tivesse escrito. Fiquei igual "minhas crianças" que vivem as aventuras como se acontecessem no quintal ou na rua casa deles."

As outras professoras passaram a relatar suas experiências de ouvintes e ao mesmo tempo de narradoras daquelas histórias que saiu da memória individual para ganhar a coletiva. As imagens acordaram o universo das imagens internas das professoras naquele momento, imagens estas "que dão forma e sentido às experiências de uma pessoa no mundo.” (MACHADO, 2000, p. 24-25). Este exercício ganhou um lugar de preâmbulo em todas as formações que tenho feito com professores.

Em uma situação recente, a professora Luci Campos, me escreveu:

-Para mim o mais importante foi perceber que o contador precisa, antes de tudo, querer contar sua própria história - mesmo que ela seja em forma de um conto tradicional, de fadas ou de um livro. A queixa da falta de tempo, da correria para ganhar dinheiro, dos poucos momentos tanto na escola quanto em casa, para a "escuta" e a "narração" é uma das principais queixas durante este momento. Uma outra professora, atuante na Educação de Jovens e Adultos, relatou: "Depois que saí daqui do curso e fui contar histórias para os alunos, eu vi que ela mexia com eles. Mas não com tudo que eles contam no dia a dia, mas com aquilo que está guardadinho." Machado diz que a 
arte, "qualquer arte verdadeira, permite este trânsito compreensível pelos significados fundamentais da vida humana."

A partir deste primeiro encontro com a narrativa, literalmente a partir de suas próprias histórias, passo a apresentar os contos como obras de arte que guardam sabedorias intocáveis, que atravessam gerações e culturas. E para aprender a contá-los é preciso contar. E, por isso, não acho possível apresentar para os professores uma lista do que pode ou não pode. Do que é certo e do que é errado na arte de contar histórias. Porque a experiência não se ensina. Ou, nas palavras de Larrosa (2002, p. 21): [...] a experiência não é o caminho até um objetivo previsto, até uma meta que se conhece de antemão, mas é uma abertura para o desconhecido, para o que não se pode antecipar nem "pré-ver" nem "pré-dizer."

A partir disso, a questão que norteia os cursos de formação que venho desenvolvendo parte da experiência de cada um: o que os contos que eu escolho dizem para mim, o que eu digo para eles e como falamos juntos?

$\mathrm{O}$ que o conto diz para mim?

Com algumas referências, cada um escolhe um jeito de compreender o conto escolhido e depois compartilha com o grupo. Para ajudá-los, apresento certas inquietações, a partir dos estudos de Regina Machado: "O clima de cada parte da história é resultante de um conjunto de elementos narrativos, animados por uma determinada pulsação." (MACHADO, 2000, p. 25). Ou seja, a pulsação de uma história de amor é diferente da pulsação de uma história de aventura, que é diferente de uma comédia, de um suspense, e assim por diante. "Viver uma história é respirar com ela." A professora Emanuela relata durante o exercício:

-Primeiro eu pergunto se eu gostei da história e se quero contá-la. Então eu começo a dividi-la em partes. Neste conto que escolhi - A Mulher Perfeita, do Nasrudin, eu pensei primeiro nas sensações. Ele anda num deserto para buscar a mulher perfeita. Eu nunca estive num deserto, mas já busquei um marido perfeito (risos). Bom, fiquei pensando nas sensações que o deserto causa e que, quem está lá também deve sentir.

O contato com estes climas certamente contribui para que as palavras "saltem" do papel e passem a habitar o narrador - provocando uma experiência leitora, ouvinte e narradora.

O que eu digo para o conto?

A professora Vanessa Santos já participou de várias oficinas depois de 2007, quando nos encontramos na UMEI Juliana, em Belo Horizonte. 
-Desde aquela primeira eu fui me aprimorando. Eu achava que não podia contar histórias e me descobri. Primeiro eu começo a ler e a degustar o texto. Tem vezes que eu até sonho com ele, acredita? Começo a aplicar em tudo, em casa com meus filhos e netos, marido, na escola, na igreja. É como se a história e seus personagens virassem personagens na minha vida. (informação verbal).

Diante deste depoimento, poderíamos dizer que Vanessa conta do ponto de vista da experiência e não tão somente do texto. É como se ela contasse a própria história enquanto conta as histórias que vêm de longe. E Vanessa continua: “ -Já tem alguns anos que fiz aquela primeira oficina com vocês, é incrível como que, com o tempo, a medida que eu fui contando histórias (tendo coragem), foi ficando mais natural narrar." (informação verbal).

Como conto e narrador falam juntos?

Como percebemos nos depoimentos dos professores, as nossas experiências de vida são essenciais, pois fazem conexões com a história a ser contada. É poder imaginar, se imaginar na pele do outro, imaginar situações vividas pelos personagens e conectá-las à própria vida, transportar-se para outra realidade que não é (e ao mesmo tempo de ser) a nossa.

A narradora Sandra Bittencourt, que começou contando histórias na educação básica, e hoje vive profissionalmente do ofício, nos diz que "uma das coisas mais importantes é conseguir estar pleno nos encontros com as pessoas. Isso só é possível quando a gente deixa a história sussurrar dentro e fora da gente." (informação verbal).

Assim como acontece no universo dos narradores tradicionais, o universo dos narradores contemporâneos também é muito diversificado. Alguns utilizam apenas a voz como principal instrumento de trabalho e a expressão corporal como um desdobramento da palavra. No primeiro caso, de maneira natural. No segundo, ensaiado. Também temos aqueles que usam outros recursos, externos, para a performance. À maneira de contadores africanos, orientais e também indígenas, a música, os tecidos e os objetos podem aparecer e geralmente estão a serviço da história.

Aposto na necessidade de situar a prática de contar histórias como uma prática artística que tem atravessado o tempo, mantendo as pessoas reunidas em volta de uma fogueira simbólica. Continua viva na sociedade atual e é constantemente recriada. Pode ser feita apenas na performance da palavra narrada, sem qualquer outro elemento, como também dialogar com diferentes linguagens artísticas, como o audiovisual, as artes plásticas, a dança, a música e o teatro. Regina Machado anuncia ainda que a observação, a disposição para brincar, experimentar, arriscar-se e ter senso de humor são recursos para ter em mãos boas ferramentas de trabalho. 
Nos trabalhos com os professores percebo que, com o tempo, à medida que os contos vão "povoando" cada um deles, os ritmos começam a ser compostos e as histórias vão nascendo de um jeito novo. E é neste momento que se faz a comunhão entre o narrador, o conto e o seu ouvinte.

\section{CONCLUSÃO}

Quando as pessoas voltaram a si, o narrador já tinha descido as escadas. Machado de Assis.

Buscamos neste artigo potencializar o debate sobre a pesquisa e a formação de professoresnarradores $^{11}$ a partir da experiência cotidiana, problematizando o enfoque narrativo como dispositivo de formação e de investigação.

Para Benjamin, a experiência está associada à percepção da e ao encontro com a diferença. Em seu ensaio Sobre a faculdade mimética (1997) Benjamin destaca a capacidade da linguagem de produzir uma semelhança imaterial entre os diferentes, ou seja, não uma imitação fiel de um modelo original, e sim a presença do (e o convívio com o) diferente num espaço comum. A universalidade das ideias não é engendrada pela presença de um sujeito transcendental, mas pela universalidade presente $n a$ linguagem. Em Benjamin, experiência e linguagem estão intimamente vinculadas, ou melhor dizendo, para ele a linguagem é a própria experiência.

A relação experiência-linguagem é o ponto de conexão entre as formulações de Walter Benjamin e de Jorge Larrosa, que nos permite pensar outros possíveis para a pesquisa e para formação de professores a partir da narrativa. Vislumbramos na articulação da ideia de "limbo" (Larrosa) com o conceito de "terna empiria" (Benjamin) um potente diálogo que pode se desdobrar em novas formulações para o uso (no sentido certeauniano do termo) da experiência e da narração no campo da pesquisa em educação e a formação de professores e ensaiamos um primeiro movimento neste diálogo, agora convidamos a você leitor a continuar esse diálogo em outros movimentos, em outros ensaios...

\section{Notas explicativas:}

${ }^{1}$ Fabiano Moraes é Doutor em Educação, Mestre em Linguística e Graduado em Letras-Português pela UFES, Professor Adjunto da Universidade Federal do Espírito Santo e idealizador e Coordenador do Portal Roda de Histórias. A narrativa apresentada, Século XX mudanças aceleradas é um fragmento do texto Um breve histórico da decadência da tradição oral no ocidente. 
${ }^{2}$ Utilizamos a junção de palavras numa mesma grafia como opção epistemológica, que define relações complementares e interdependentes como um mesmo fluxo. Entendemos que saberes e fazeres se articulam ao processo de conhecimento no movimento de articulação práticateoriaprática.

${ }^{3}$ Idem nota número 2.

${ }^{4}$ Narrativa As borboletas tem como autor Leandro Delgado, Mestre em Educação pela UFF e Professor do Ensino Fundamental I da Rede Municipal de Educação de Juiz de Fora - MG e foi apresentada na disciplina Memória e Narração em Educação, ministrada no Programa de Pós-Graduação em Educação da Universidade Federal Fluminense.

${ }^{5}$ A Narrativa de Fabiano Moraes é uma das formas que o autor se apresenta - uma autobiografia - em cursos ou oficinas que ministra para e com professores.

${ }^{6}$ A Narrativa $O$ caminho da escola é uma produção de Lícia Maciel Hauer, Doutora em Educação pela UFF e professora do Ensino Fundamental II do Colégio Pedro II - RJ, e foi apresentada na disciplina Memória e Narração em Educação, ministrada no Programa de Pós-Graduação em Educação da Universidade Federal Fluminense.

${ }^{7}$ Narrativa $O$ Piano é uma produção de Marcia Nico Evangelista, doutoranda em Educação e professora do Ensino Fundamental da Rede Municipal de Educação de Niterói, e foi apresentada na disciplina Memória e Narração em Educação, ministrada no Programa de Pós-Graduação em Educação da Universidade Federal Fluminense.

${ }^{8}$ Narrativa Corpos que costuram, lugares do escrever, de autoria de Lorena Lopes Pereira Bonomo, foi apresentada na disciplina Memória e Narração em Educação, ministrada no Programa de Pós-Graduação em Educação da Universidade Federal Fluminense, quando a então professora de Geografia do Ensino Fundamental II da Rede Municipal de Educação do Rio de Janeiro cursava o Doutorado naquela instituição. Hoje Lorena Bonomo é Doutora em Educação pela UFF e Professora da Universidade do Estado do Rio de Janeiro/Faculdade da Baixada Fluminense - UERJ/FEBEF.

${ }^{9}$ Narrativa A Memória das histórias, de Aline Cântia, narradora e contadora de histórias, que desenvolve um trabalho de formação de professores a partir das narrativas que as professoras elaboram de suas experiências pessoais e coletivas. Aline é doutoranda em Educação no Programa de Pós-Graduação em Educação da Universidade Federal Fluminense.

${ }^{10}$ Para ser coerente com a discussão apresentada optamos por refletir a relação Narrativa-Experiência na Formação de Professores a partir de uma experiência vivida com professoras da educação infantil.

${ }^{11}$ Idem nota número 2.

\section{REFERÊNCIAS}

BENJAMIN, W. Magia e Técnica, Arte e Política - Obras Escolhidas. 8. ed. São Paulo: Brasiliense, 2012. v. 11.

BENJAMIN, W. Charles Baudelaire um lírico no auge do capitalismo. São Paulo: Brasiliense, 2008.

BENJAMIN, W. Sobre el lenguaje en general e sobre el lenguaje de los ombre. In: BENJAMIN, W. Sobre el programa de la Filosofia Futura y otros ensayos. Caracas: Monte Avilla Editores, 1997.

BENJAMIN, W. O narrador - Considerações sobre a obra de Nikolai Leskov e "Experiência e Pobreza. In: BENJAMIN, W. Magia e técnica, arte e política: ensaios sobre literatura e história da cultura. Tradução Sérgio Paulo Rouanet. 7. ed. São Paulo: Brasiliense, 1994. 
BONOMO, L. L. P. Políticas e Poéticas Infantis na Invenção de Lugares-Comuns. Tese (Doutorado em Educação)-Universidade Federal Fluminense, Niterói, 2015.

DELGADO, L. J. Narrativas e Práticas Docentes: reinventando o cotidiano escolar. Dissertação (Mestrado em Educação)-Universidade Federal Fluminense, Niterói, 2015.

DOMINICÊ, Pierre. O processo de formação e alguns de seus problemas relacionais. In: NÓVOA, A.; FINGER, M. (Org.). O método (auto)biográfico e a formação. Lisboa: Ministério da Saúde, 1998.

FREIRE, Paulo. Pedagogia da Autonomia. São Paulo: Paz e Terra, 1996.

FOUCAULT, Michel. O que é um autor. Lisboa: Veja, 1992.

LARROSA, J. Tremores. Escritos sobre experiência. Belo Horizonte: Autêntica, 2014.

LARROSA, J. O papel da educação é subverter as regras. Entrevista com Jorge Larrosa. In: Envolverde. Jornalismo\&Sustentabilidade. Publicado em 12 abr. 2013. Disponível em: <http://www.envolverde.com.br/educacao>. Acesso em: 19 set. 2015.

LARROSA, J. O professor ensaísta. Entrevista com Jorge Larrosa. Revista Educação, ed. 193, maio 2013. Disponível em: <www. revistaeducacao.com.br>. Acesso em: 19 set. 2015.

LARROSA, J. Palavras desde o limbo. Notas para outra pesquisa na educação ou, talvez, para outra coisa que não a pesquisa na educação. Revista Teias, v. 13, n. 27, 2012. Disponível em: <http://www.periodicos.proped.pro.br>. Acesso em: 11 dez. 2012.

LARROSA, J. Notas sobre a experiência e o saber de experiência. Revista Brasileira de Educação, n. 19, jan./abr. Tradução João Wanderley Geraldi. São Paulo: Autores associados, 2002.

LARROSA, Jorge. Las paradojas de la autoconciencia - Un cuento, con prólogo y moraleja, según algunos fragmentos de las Confesiones de Rousseau. In: RODRÍGUEZ, M. L.; LARROSA, J. (Org.). Déjame que te cuente - ensayos sobre Narrativa y Educación. Barcelona, Espanha: Editorial Laertes, 1995.

LEAL, B. Escrever é inscrever-se (na forma de um prefácio). In: LACERDA, M. A escrita inscrita na formação docente. Rio de Janeiro: Rovelle, 2009. 
MACHADO, R. Acordais - Fundamentos teórico-poéticos da arte de contar histórias. São Paulo: DCL,

MACHADO, R. Arte-educação e o conto de tradição oral: elementos para uma pedagogia do imaginário. Tese (Doutorado em Comunicação e Artes)-Universidade de São Paulo, São Paulo, 1989.

MORAES, F. Um breve histórico da decadência da tradição oral no ocidente. Portal Cultura Infância. Disponível em: <http://www.culturainfancia.com.br/>. Acesso em: 22 set. 2015.

MORAES, F. Contação de Histórias: Tiro o chapéu e me apresento. Portal Cultura Infância. Disponível em: <http://www.culturainfancia.com.br/>. Acesso em: 22 set. 2015.

MATOS, G. A. A palavra do contador de histórias: sua dimensão educativa na contemporaneidade. São Paulo: Martins Fontes, 2005.

MATOS, G. A.; SORSY, I. O ofício do contador de histórias. São Paulo: Martins Fontes, 2005.

PÉREZ, C. L. V. Professoras Alfabetizadoras. Histórias plurais, práticas singulares. Rio de Janeiro. D.P\&A, 2003.

PEREZ, C. L.V.; LEITE, C. D. P. Quem é esse menino que faz do mundo outro menino? Trabalho apresentado na $37^{\mathrm{a}}$ Reunião Anual da ANPEd - GT 13, Florianópolis, Santa Catarina. Disponível em: < http://37reuniao.anped.org.br/trabalhos/>. Acesso em: 09 out. 2015.

Recebido em: 15 de outubro de 2015

Aceito: 13 de fevereiro de 2016

Endereço para correspondência: Miguel de Frias, 9, Icaraí, 24220-900, Niterói, Rio de Janeiro, Brasil; clvperez@gmail.com 